$\xi=$ 圈

\title{
Comparative analysis of storage techniques for a grid with renewable energy sources
}

\author{
Surender Reddy Salkuti ${ }^{1}$, Chan-Mook Jung ${ }^{2 *}$ \\ ${ }^{I}$ Department of Railroad and Electrical Engineering, Woosong University, Daejeon, Republic of Korea \\ ${ }^{2}$ Department of Railroad and Civil Engineering, Woosong University, Daejeon, Republic of Korea \\ *Corresponding author E-mail: cmjungwsu2013@gmail.com
}

\begin{abstract}
This paper presents the comparative analysis of different energy storage techniques used in the utility grid connected with the renewable energy sources (RESs). Energy storage is required to match the demand and supply of energy. However, with the integration of RESs to the grid increases the mismatch between the supply and demand due to the intermittence of RESs. In this paper, it is shown that the energy stor-age systems provide a better solution to the integration of different RESs to the existing grid. The energy storage systems are the key com-ponents for replacing the conventional fossil fuel plants with RESs. It is hard to evaluate the different types of energy storage techniques between themselves due to the fact that each technology could be used in a different way and are more like compliments. Further, research needs to be done on storage techniques to continue to increase the benefits while reducing the associated costs. The energy storage tech-niques show great potential to help the RESs and smart grid to meet the world's growing energy demand. This paper has presented the comparative analysis of various energy storage systems in terms of their design, cost, geographical location, advantages and disadvantages.
\end{abstract}

Keywords: Renewable Energy Sources; Energy Storage; Smart Grid; Flywheel; Battery; Microgrid; Supercapacitors.

\section{Introduction}

The demand for energy in the world has been growing rapidly. The current trends indicate that the world would be facing constraints in indigenous availability of conventional energy resources. These demands has to be met in an equitable and sustainable manner. Therefore, there is a requirement for incorporating the renewable energy sources (RESs) into the grid. The two main issues with the integration of RESs to the grid are the variability and unpredictability. To accommodate these issues, the scheduled productions and consumptions in an electricity market are required to be modified during the actual operation of power system. The increasing penetration levels of RESs will change considerably all aspects concerning the operational and reliability performance of utility grids. Hence, it is necessary for energy to be stored and combined to help the demand on green energy. Energy storage is the way energy is being conserved in a particular form and then released when needed in the same form or converted to a different form [1].

A review on the structures and applications of Flywheel energy storage system in power system, microgrid; and the challenges, problems and future works are presented in [2]. Reference [3] describes the requirement to store energy to strengthen power networks and to maintain load levels. Latest energy storage technology profile is analyzed and described in [4], in terms of technology maturity, efficiency, scale, lifespan, cost and applications. A comprehensive overview of important electrical energy storage systems has been presented in Reference [5]. Reference [6] presents an overview of storage batteries and compares their technical properties such as the power and energy densities, cycle life, efficiencies and costs. A multi-period market-equilibrium model of interactions between different types of market agents is presented in Reference [7]. Reference [8] proposes a multi-period optimization model to study the technical and economic effects of placement and use of RESs and energy storage systems in an electrical system. An overview of battery sizing criteria, methods and its applications in various RESs is presented in [9]. The integration of RESs considering the installation of a battery energy storage system into an isolated power grid is assessed in [10]. A comprehensive comparison of various technical characteristics and features of different storage technologies is presented in [11]. The behavior of battery and flywheel storage systems in photovoltaic (PV) and wind energy applications is presented in [12]. A model to optimize the design of a biomass-integrated microgrid employing combined heat and power with energy storage is developed in [3]. An overview of innovative field of hybrid energy storage systems is described in [14]. A multi-level perspective model to examine the development of policy frameworks around energy storage technologies is presented in [15]. Reference [16] presents the issues of electricity storage requirements based on comparative studies of various results. However, there is a requirement for a comprehensive review of various storage systems for the integration of RESs to the utility grid.

The objective of the present paper is to present the comparative analysis of different energy storage technologies used in the grid connected with the renewable energy sources (RESs). In this paper various storage techniques such as storage batteries, compressed air energy storage (CAES) systems, flywheels, pumped hydro energy storage systems, supercapacitors and superconducting magnetic energy storage (SMES) systems are discussed and compared in a detailed manner.

The rest of the paper is organized as follows. Section 2 presents the integration of energy storage with the RESs. The comparative 
analysis of various energy storage techniques is described in Section 3 . The contributions with concluding remarks has been presented in Section 4.

\section{Integration of energy storage with renewa- ble energy sources (RESs)}

Renewable power generation has several advantages and disadvantages. One major advantage of renewable energy is that it can never be depleted and require very little maintenance reducing the cost of production. It is environmentally friendly as they don't emit pollutants or create waste that destroys the air and our ecosystem. However, the amount of energy produced is not as huge as that of fossil fuel. Renewable energy depends greatly on nature to produce power and is not always reliable. As it is a new technology, it is expensive to create and install this technology, but with time the price will reduce as more people switch to renewable energy. A great way to sustain renewable energy is through storage devices [17].

Due to the intermittency that arises with RESs, various energy storage techniques have to be integrated into the system. Energy storage will help to provide a buffer for periods of imbalance with power demanded and supplied. Improved storage facilities will also help the RESs to address transmission issues that result from geographical challenges and easing availability for consumers. In these grids, generally, supercapacitors are used for short-term storage, which runs is considered to be about a few microseconds, while batteries are used for long-term storage [18]. Figure 1 depicts the classification of various energy storage systems. They are classified into direct and indirect storage systems [19]. Storage batteries, flywheels, pumped hydro energy storage and compressed air energy storages comes into the indirect energy storage category. Whereas, supercapacitors and superconducting magnetic energy storage comes into the direct energy storage.

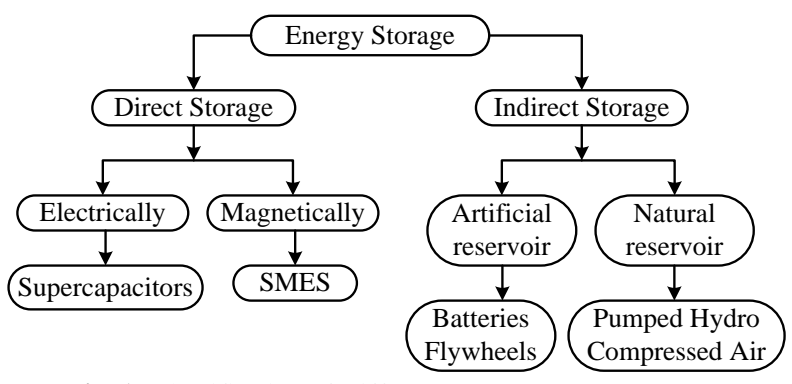

Fig. 1: Classification of Different Energy Storage Systems.

As the renewable power generation grows up, it will ultimately overwhelm the ability of conventional power sources to compensate the variability of RESs, and require the capture of electricity generated by wind, solar PV and other renewables for later use [20]. The energy storage techniques will play a huge part in the future of power generation. The high level benefits that will be felt from storage techniques are presented next:

Reducing reserve power plants: The reserve power plants are setup to shave peak demands. Nuclear power plants aren't used for this purpose because its more economically effective to use the plants to provide base power. They have problems responding to rapid demand changes. Hydroelectric plants can respond quickly to load demand changes but the cost to build and maintain these plants solely for demand shaving is very high. It is desirable to reduce the number of reserve power plants because these power plants are expensive and old. Also, they are non-environmentally friendly because of the dirty fossil fuels that power the plants. Whereas, the energy storage techniques can both store power during demand valleys and shave peak demand with low emissions Reducing the costs associated with power outages: Power outages is a huge problem because they affect many facets of our world. Most businesses in our economy rely on energy to support the proper functioning of their company. In many power outages, businesses cannot operate. Specifically, 79 billion dollars are lost annually to service interruptions that last for less than 5 minutes. Storage devices can provide power until back-up power is made available. Utility companies that serve areas that often lose service can delay making short-term improvements by implementing storage techniques and concentrating on making better, more strategic long term improvements to their smart grid [21].

Supporting RESs: With the addition of storage techniques, the RESs can reduce the variability in their power output. Specifically, wind and solar PV power, because these are currently the most sustainable RESs. Various storage technologies are selected based on the different parameters, such as power capacity, discharge duration, response time, discharge frequency, ease of integration with the existing grid, storage capacity, product lifespan, efficiency, transportability and the operating cost.

\section{Comparative analysis of different storage technologies}

With the integration of RESs into the grid, the energy storage techniques can be classified as [19]:

- Electrochemical systems: Batteries, fuel cells.

- Thermal systems: Water or oil heaters.

- Mechanical systems: Flywheels.

- Pneumatic systems: Air compressors.

- Magnetic systems: Superconducting magnetic energy storage (SMES) systems.

- Electric systems: Supercapacitors.

\subsection{Storage batteries}

Batteries can be found in many different forms which include lithium ion, sodium-sulphur, flow, and lead acid. Because of their high cost and/or short lifetime, they are only used in a limited number of applications. Advanced batteries are being fabricated, designed, and built as the trend of using motor vehicles is increasing. It has a serious environmental impact which is leading to the air pollution in large cities and densely populated areas. As a result, the manufacturers, power industry, battery researchers and exporters around the world have meetings to communicate and focus on the basis of distributing better and prevent the environment from hurting people.

The power is directly proportional to the voltage and current. As it relates to battery energy storage, different batteries have different voltage and current characteristics based on their internal make-up. For example, lithium ion batteries can store more energy per given volume than other batteries such as nickel-cadmium and lead acid. This means that they can handle larger voltage and current values for a given volume. Furthermore, considerations on how much electricity and time a given battery needs to charge are important. Just like other storage systems, things such as round-trip efficiency must be evaluated. Advanced batteries include the lithium-ion, lead-acid, metal-air, zinc-bromide batteries. These batteries are rechargeable.

These batteries are electrochemical cells that contain a nonaqueous electrolyte and an intercalated compound as positive electrode. When the battery is charged, the voltage reverses the current flow from positive to negative. After the energy is stored the battery discharges current from negative to positive. These essentially are the electrochemical cells consisting of an intercalated compound as positive electrode, a non-aqueous electrolyte (usually a salt dissolved in an organic solvent), and a negative electrode (for which graphite is commonly used). The battery is charged by an external power circuit which supplies an over-voltage and reverses the regular flow of current in the battery and makes the positive ions migrate from the positive to negative electrode, hence a flow of current in the opposite direction. During discharge, the positive ions carry current from the negative to positive electrode and hence stored energy is given up. Batteries for energy storage can 
be easily constructed to fit specific needs and are thus available in various shapes and sizes [22].

Features of energy storage batteries:

- Banks of lead-acid batteries are commonly used to stabilize electrical systems by supplying extra power and maintaining voltage and frequency levels.

- Lead acid batteries have very low life spans when charged and discharged frequently.

- Flow batteries store electrolytes outside itself and circulate these electrolytes to generate electricity. Because these batteries create a substrate but are not involved in any chemical reaction, the flow batteries have long life spans.

- Nickel-metal hydride have relatively low energy densities and are very sensitive. They tend to have problems with overcharging.
- Rural locations utilize portable sodium-sulphur battery systems to provide power for small time periods.

- Lithium-ion (Li-ion) batteries are commonly used in mobile phones and laptop computers. In comparison with nickelcadmium and lead acid batteries, they have a much higher energy density. Their long lifetimes make them a very good cost option.

- Manufacturing of batteries poses as huge safety and environmental risk due to the involvement of large number of chemicals [23-24].

Table 1: Cost, Advantages and Disadvantages of Storage Batteries.

Cost
- The cost of batteries varies depending on the type of battery
chosen. At the low end, alkaline batteries cost $190 \$ / \mathrm{kWh}$. At
the high end, nickel-cadmium batteries cost $1500 \$ / \mathrm{kWh}$.
The U.S. Advanced Battery Consortium has set a target of
150\$/kWh for the cost of Li-ion battery to make it accessible
by the mass market by year 2020 .

The common usage of batteries have created many concerns dealing with the environment which include toxic metal pollution. Battery manufacture often involves hazardous chemicals which harm the environment. Used batteries also contribute to this problem. In many areas across the nation, many people have taken upon themselves and have demanded for battery recycling. Ultimately, recycling or simply properly disposing these batteries helps prevents dangerous elements such as lead, mercury, and cadmium found in some types of batteries from entering our environment.

\subsection{Compressed air energy storage (CAES) system}

The CAES is used for compressing air that is stored deep under the ground. The CAES system prevents the wind production from hurting people, plants, and animals. It also has the potential to reduce the risk for renewable projects and to reduce of the wind curtailment and increased the possibility. As a result, the combination of wind production and CAES overall value is increased and produce the best wind power which is being delivered to the market as daily basis. The overall efficiency of CAES system is provided by the reduction of carbon emission. The decrease of reliance on thermal production and increase overall efficiency leads to the vast reduction of carbon emission provided by the CAES. It is also important for the safety of fossil fuels that is being produced since it is reducing the carbon mission and thermal production. It is used for energy generated at one time and utilized it for many days. When it comes out of the ground, it is released through the turbines, which drives the rotor of an electric current generator, in the form of heat [25].

The CAES system utilizes high efficiency compressors to store air underground. Like most storage techniques, the energy is stored during low cost and low demand time periods. When the electricity demand, the air expands to atmospheric pressure which causes turbines to generate electricity that can be used by the smart grid. When air compression is taking placed, then the rotor/generator is

Advantages

Lithium-ion batteries have the following

advantages:

- $\quad$ They can be produced in various shapes or sizes to fit whatever need they are to meet.

- Low self-discharge rate.

- $\quad$ Lighter weight in comparison to other equivalent secondary cells.

- It is relatively safe for the environment, and helps to reduce carbon emissions from vehicles.

- High discharge duration at maximum power level.

- No memory effect.

- Batteries are highly portable, and Disadvantages they can be placed almost anywhere.

connected to both the compressor and turbine. However, during the production of current, the motor/generator is disconnected from the compressor and connected to the turbine. Compressed air unit burns only one-third of the fuels used by the turbines to make the same electricity production which leads to the two-third of reduction in the environmental pollution [26].

The optimization of air compression that was released in the form of air combustion back to the energy system is cost effective. As much as $1.7 \mathrm{k}$ of air compression is needed for every hour of electric current production that is operated above $25 \mathrm{MW}$. The response time of this process is estimated to be about 10 minutes with the efficiency of air compression is in between (65-75)\%.

The basic principle of operation of CAES system is that energy is stored during off-peak periods of electricity demand in underground formations' or caverns. These caverns are either created by solution mining or by using an abandoned mine. In periods of peak demand, i.e., most often during the day, the stored compressed air is then heated and used to drive a steam turbine [27].

Features of CAES System:

- They can be operate for short time periods to fix the voltage sags.

- They are used to power small scale distributed generation systems.

- Fast response time.

- Low risk of tanks rupturing because of high-pressure nature of system.

- They are located in salt caverns or domes. 
Table 2: Cost, Advantages and Disadvantages of CAES System.

\begin{tabular}{|c|c|c|c|}
\hline Cost & & Advantages & Disadvantages \\
\hline $\begin{array}{l}\bullet \\
\bullet \\
\bullet\end{array}$ & $\begin{array}{l}\text { According to the Electric Power Re- } \\
\text { search Institute, the price of CAES } \\
\text { system is about } 1000 \$ / \mathrm{kWh} \text {. } \\
\text { In that, the capital costs are in the } \\
\text { range of }(600-700) \$ / \mathrm{kW} \text {. } \\
\text { This cost include the costs of setting } \\
\text { up the underground storage intercool- } \\
\text { ers for dissipating the heat, and com- } \\
\text { pressors and expanders for the air. }\end{array}$ & $\begin{array}{l}\text { - CAES systems can be easily optimized to } \\
\text { fit any specific site. } \\
\text { They are capable of black starts, i.e., they } \\
\text { are able to start up from shut down condi- } \\
\text { tion without depending on the grid for } \\
\text { power. } \\
\text { They provide a great economic benefit as } \\
\text { it stores energy while demand is low } \\
\text { (hence, energy at lower cost) and supplies } \\
\text { this energy in times of peak demand, when } \\
\text { the cost is higher. } \\
\text { Exploitation of this method of storage can } \\
\text { lead to creation of employment opportuni- } \\
\text { ties with regards to the human resources } \\
\text { required for execution. } \\
\text { They have high energy storage capacity } \\
\text { and power output. } \\
\text { They have high discharge duration at max- } \\
\text { imum power output. }\end{array}$ & $\begin{array}{l}\text { The efficiency of the system is relatively } \\
\text { low. Some demonstrations have managed to } \\
\text { show efficiencies as high as } 75 \% \text {, however } \\
\text { other demonstrations have shown efficien- } \\
\text { cies as low as } 40 \% \text {. } \\
\text { The underground caverns are seen as risk } \\
\text { issues by the utility companies. } \\
\text { - Slow response time. }\end{array}$ \\
\hline
\end{tabular}

\subsection{Flywheels}

Flywheel is a mechanical storage device that is used to store the rotational energy. They have moment of inertia, and resist changes in rotational speed. It absorbs energy and acts as a reservoir. Torque is applied to a flywheel to transfer energy. This increases the rotational speed and the stored energy. When torque is applied to a mechanical load, the flywheel releases the energy stored and this decreases its rotational speed. Flywheels have quick response times and are low maintenance. Flywheels are able to absorb energy within seconds or minutes and can disburse energy rapidly [28].

A spinning disk on a metal shaft represents the storage location of a flywheel system. Increasing the speed of rotation, mass of the disk, or moving the mass closer to the rim of the disk increase a flywheel's storage capacity. Flywheels are most often used for applications requiring short discharge time. These types of applications normally refer to voltage and frequency stabilization. Flywheels energy storage is functioned using the accelerating rotor to maximum speed level and keep the energy in the system in the form of rotational energy. However, when the energy is somewhat destructed, then the flywheel's rotation speed tend to reduce. In some vehicles which use diesel in order to function and being used for transportation tend to contain flywheels which can reduce the fuel consumption and prevent the environment from pollution
These reductions of pollution and fuels using the flywheels also have the important factor which is saves the money [29].

The flywheel is constructed with a rotor suspended by magnetic or mechanical bearings and rotates inside a vacuum chamber, all within a shell for safety [30-31]. This is then connected to a system (usually a generator). Based on the principle of conservation of energy, the flywheel stores energy when it spins and supplies energy when needed. Rotors made from plastic re-enforced with high tensile strength fibres with up to $100000 \mathrm{rpm}$ can store more energy per volume or weight than rotors made from high tensile steel with approximately $10000 \mathrm{rpm}$. The flywheel is coupled to a conventional electric generator, which generates electricity when breaking the flywheel [32].

Features of flywheels:

- Third generation flywheels mix high mass and rotational speed to maximize overall storage.

- Flywheels have varying discharge capabilities. They can be used in short or long duration discharges.

- Current technology sets a restriction on the dual discharge nature. High cost and limited capacity are issues.

- Flexible sizing and installation.

- Small volume and weight.

- $\quad$ Operating range is $\left(32^{\circ}-104^{\circ}\right) \mathrm{F}$.

Table 3: Cost, Advantages and Disadvantages of Flywheels

\begin{tabular}{|c|c|c|}
\hline Cost & Advantages & Disadvantages \\
\hline $\begin{array}{l}\text { The costs of flywheel energy storage technique include: } \\
\text { - Capital cost: This refers to the cost of installing a } \\
\text { complete system. } \\
\text { - } \quad \text { Regulation cost. } \\
\text { - } \quad \text { Opepreciation cost. } \\
\text { - The cost of a Flywheel energy storage is estimated } \\
\text { to be about } 1630 \$ / \mathrm{kW} \text {. This include the operation- } \\
\text { al cost, regulation cost, and depreciation cost. }\end{array}$ & 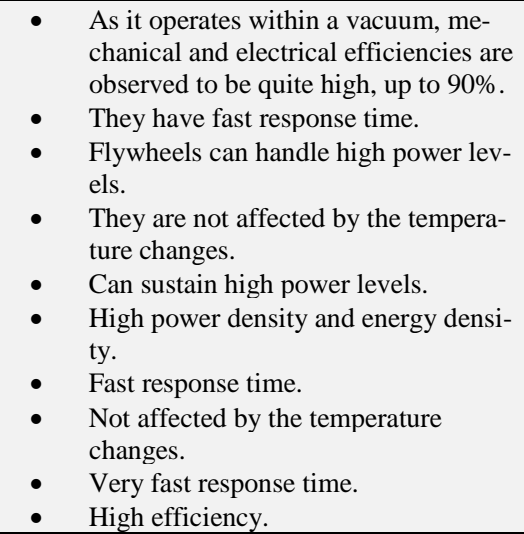 & $\begin{array}{l}\text { There is a risk of flywheel explo- } \\
\text { sion, which creates the need for } \\
\text { stronger containment vessels. } \\
\text { Short energy storage time, due to } \\
\text { energy loss through friction due to } \\
\text { the dynamic orientation of the earth. } \\
\text { - } \quad \text { Gyroscopic effects. } \\
\text { Energy is lost through friction be- } \\
\text { cause of the dynamic orientation of } \\
\text { the earth. } \\
\text { Relatively low discharge time at } \\
\text { maximum power level. }\end{array}$ \\
\hline
\end{tabular}

The flywheel energy storage is used in different areas. Some examples are rail electrification, where it decreases the harmonics in low voltage power networks, and wind-diesel generator [33-34].

\subsection{Pumped hydro energy storage (PHES) system}

This is the largest-capacity form of grid energy storage available and is reported to account for over $90 \%$ of the bulk storage capaci- ty around, accounting for about 127,000 MW. The PHES method is very straightforward, and can be seen as a modification of regular hydroelectric dams [35]. In times of low electricity demand, excess available energy is used to pump water to a higher reservoir. The pumped water which now possesses gravitational potential energy is stored at a high point in the reservoir till the energy is needed. In periods of peak energy demand, the water is then released from the top of the reservoir and used to turn the turbine 
to produce electricity. This helps to raise revenues obtained from a fixed amount of resources as energy is stored at low-cost and made available at a higher cost in periods of peak demand [36].

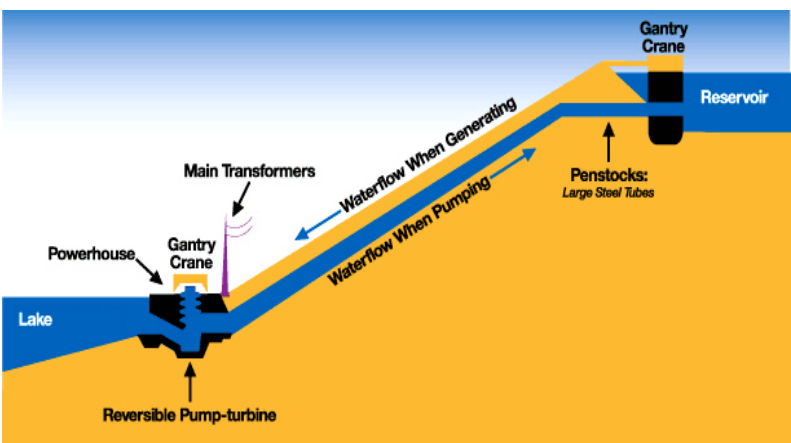

Fig. 2: Pumped Hydro Electric Storage (PHES) System.
Features of PHES system:

- Pump turbines operate at $\pm 10 \%$ of a conventional pump turbine.

- Capable of adjusting electricity generation by $70 \%$.

- Capable of adjusting storage capacity by $40 \%$.

- PHES systems can regulate the frequency in two different modes, i.e., in pump mode and in generation mode.

- Resonances can be avoided due to variable frequency which increases the product lifespan and reduces the maintenance.

- Power output can be changed very quickly in (10-30)ms.

- Requires large generation station and close proximity to a water reservoir.

Table 4: Cost, Advantages and Disadvantages of PHES System

\begin{tabular}{|c|c|c|}
\hline Cost & Advantages & Disadvantages \\
\hline $\begin{array}{l}\text { The Electricity Storage Association has esti- } \\
\text { mated the costs for PHES systems are in the } \\
\text { range of }(500-1500) \$ / \mathrm{kW} \text {. }\end{array}$ & $\begin{array}{l}\text { - They are environmentally safe. } \\
\text { - } \quad \text { can be used on a very large scale to pro- } \\
\text { vide high levels of power. } \\
\text { - It is a self-sufficient method of storage. } \\
\text { It is a further developed method than most } \\
\text { others as various innovations have been } \\
\text { introduced over the years. } \\
\text { - } \quad \text { Easily enhanced to meet any requirement. } \\
\text { - } \quad \text { without the help of power from a grid. } \\
\text { - Low start-up time. } \\
\text { - } \quad \text { Very high storage capacity and lifespan. }\end{array}$ & $\begin{array}{l}\text { - The generator must be below the sea level. } \\
\text { It will conflict with aquatic life in the area } \\
\text { and will either damage their habitat, or the } \\
\text { equipment could get damaged. } \\
\text { Can only be implemented in certain areas } \\
\text { close to water. } \\
\text { - The underground caverns are a big risk. } \\
\text { - Relatively low efficient. }\end{array}$ \\
\hline
\end{tabular}

PHES system is a well-developed means of storage and is important due to its capability in handling very large power, covering a range from about (200-2000) MW [37]. They don't release any green house gasses and uses renewable energy as fuel source. The PHES systems should be located in a place that can allow for the water to be raised to a considerably high elevation. They require sufficient space for the storage facility to be built [38].

\subsection{Supercapacitors}

Supercapacitors are an electrochemical double layer capacitor that contains electrodes with a membrane as a separator and an electrolyte. A supercapacitor is a special type of capacitor that differs from regular capacitors because of its storage capability or it capacitance. These capacitors store energy using two oppositely charged electrodes which are separated using an ionic solution. Energy is stored when ions attach to the electrodes and released when ions return to the solution [39].

Usually, the capacitors work by the potential difference across the conductor or the two plates. A static charge builds across the dialectic part causing charge to collect on the plates. The energy from the charging of the plates is stored in the electrostatic field. The supercapacitor is of the type that is rated in Farads, meaning it would be a good choice for storing energy in a smart grid set up that calls for frequent charge and discharge cycles at high current because of the high capacitance. There are three main factors that determine how much energy a capacitor can store, and they are: electrode surface area, the materials that separates the plates' dielectric constant, and distance the plates are from each other.

They store energy by the separation of membranes. When a supercapacitor is charged it helps put charges onto the plates. The plates are then neutralized and energy flows out when electricity is needed. Like batteries, capacitors are highly portable because of their size [40].

Features of Supercapacitors:

- Increasing the electrode surface area, increases the amount of stored energy.

- Symmetric capacitors with activated carbon electrodes are the most widely used.

- Asymmetic capacitors have higher operating voltages and more ability to stay within the rated voltage constraints. Also, they have packaging and manufacturing advantages over symmetric capacitors.

- Capacitors are generally used to remedy short power interruptions.

- Good at stabilizing voltage and frequency levels.

- Connecting capacitors together can increase the duration of time that they can fix power interruptions.

- High power density.

- Performance is independent of temperature.

- Very low maintenance.

- Lifespan of up to 20 years.

Table 5: Cost, Advantages and Disadvantages of Supercapacitor

\begin{tabular}{|c|c|c|}
\hline Cost & Advantages & Disadvantages \\
\hline $\begin{array}{l}\text { The cost of supercapacitors are in the range } \\
\text { of }(2400-6000) \$ / \mathrm{kWh} \text {. }\end{array}$ & $\begin{array}{l}\text { Very high rates of charge and dis- } \\
\text { charge. } \\
\text { - High specific power and efficiency } \\
\text { (up to 95\%). } \\
\text { - Improved safety, as the materials } \\
\text { used have low toxicity. } \\
\text { - Low cost per cycle. } \\
\text { - Fast response time. } \\
\text { - Long lifespan. }\end{array}$ & $\begin{array}{l}\text { - Though having a high power density, it's energy } \\
\text { - } \quad \text { High self-discharge. } \\
\text { - Cannot be singly implemented, except in series } \\
\text { - } \quad \text { High dielectric absorption. } \\
\text { - Low energy storage capacity. } \\
\text { - Low discharge duration at maximum power level. }\end{array}$ \\
\hline
\end{tabular}




\subsection{Superconducting magnetic energy storage (SMES) system}

In the SMES system, the electric current is stored indefinitely inside of superconducting windings. There are very low resistive losses. Also, SMES has the capability to quickly discharge high power for brief time spans [41]. Larger coils correspond to more power capacity. As the coils become larger, the magnetic field increases. At a point, the superconducting properties of the windings begin to break down and the coolant necessary to keep the machine operable becomes very expensive [42].

Features of SMES system:
- $\quad$ Altering the current in the windings allows energy to be put in or taken out of the system.

- At steady state, energy can be maintained indefinitely.

- SMES has high reliability and low maintenance, as the main part is motionless.

- The refrigeration systems that cool the SMES have energy losses because they have moving parts.

- High power can be released instantaneously. Although, this power level can only be sustained for a short period of time.

- Networking several SMES systems together can increase the energy available.

Table 6: Cost, Advantages and Disadvantages of SMES System

\begin{tabular}{|c|c|c|}
\hline Cost & Advantages & Disadvantages \\
\hline $\begin{array}{l}\text { The cost of SMES system is approximately } \\
4.2 \text { million dollars for a } 3.3 \mathrm{~kW} \text { prototype. } \\
\text { For a toroidal design, it costs approximate- } \\
\text { ly } 2000 \$ / \mathrm{kWh} \text {. }\end{array}$ & $\begin{array}{l}\text { - SMES system has fast response time with its ability } \\
\text { to switch from charge to discharge state within sec- } \\
\text { onds. This is beneficial because there is no real } \\
\text { waiting time for this system to regenerate. } \\
\text { - High efficiency. } \\
\text { - Long lifespan. }\end{array}$ & $\begin{array}{l}\text { Need a large amount of power to } \\
\text { keep the coil at low temperatures, } \\
\text { combined with the high overall cost } \\
\text { for the employment of a unit. } \\
\text { - Low storage capacity and power out- } \\
\text { put. } \\
\text { Low discharge duration at maximum } \\
\text { power level. }\end{array}$ \\
\hline
\end{tabular}

\section{Conclusions}

The energy storage technologies will increase the supply, and balances out the demand for energy in the system connected with the renewable energy sources (RESs). This paper addressed various energy storage techniques, i.e., storage batteries, compressed air energy storage (CAES) systems, flywheels, pumped hydro energy storage (PHES) systems, supercapacitors and superconducting magnetic energy storage (SMES) systems in a grid connected with RESs. Different storage techniques are compared in terms of mode of operation, features, cost, advantages and disadvantages. The SMES system is portable and easily deployable yet very expensive per $\mathrm{kW}$. The PHES system is inexpensive and effective yet has geographic drawbacks as the site needs to be near water so it can only perform in coastal areas. The CAES system has low maintenance and relatively inexpensive but a cavern is needed and the amount of air being compressed could be a potential hazard. Flywheels have a very quick response time as it can absorb energy in a matter of seconds and it is inexpensive. Supercapacitors on the other hand are safe, portable, the least inexpensive, low maintenance, and have the shortest charge time. This storage technique is ideal because it delivers the most benefits with the least costs. The flywheels can remain for longer duration storing energy and as a result they are useful systems for electrical grid use.

\section{Acknowledgment}

This research work is based on the support of "Woosong University's Academic Research Funding - 2018".

\section{References}

[1] J. Gustavsson, Energy Storage Technology Comparison, Bachelor of Science Thesis, KTH School of Industrial Engineering and Management Energy Technology, Stockholm, 2016. Available. [Online]: http://www.divaportal.org/smash/get/diva2:953046/FULLTEXT01.pdf

[2] A.A.K. Arani, H. Karami, G.B. Gharehpetian, M.S.A. Hejazi, Review of Flywheel Energy Storage Systems structures and applications in power systems and microgrids, Renewable and Sustainable Energy Reviews, vol. 69(C), (2017), pp. 9-18. https://doi.org/10.1016/j.rser.2016.11.166.
[3] H. Ibrahim, A. Ilinca , J. Perron, Energy storage systemsCharacteristics and comparisons, Renewable and Sustainable Energy Reviews, vol. 12, (2008), pp. 1221-1250. https://doi.org/10.1016/j.rser.2007.01.023.

[4] L. Yao, B. Yang, H. Cui, J. Zhuang, J. Ye, J. Xue, Challenges and progresses of energy storage technology and its application in power systems, Journal of Modern Power Systems and Clean Energy, vol. 4, no. 4, (2016), pp. 519-528. https://doi.org/10.1007/s40565-016-0248-x.

[5] P. Nikolaidis, A. Poullikkas, A comparative review of electrical energy storage systems for better sustainability, Journal of Power Technologies, vol. 97, no. 3, (2017), pp. 220-245.

[6] D. Akinyele, J. Belikov, Y. Levron, Battery Storage Technologies for Electrical Applications: Impact in Stand-Alone Photovoltaic Systems, Energies, vol. 10, no. 11, (2017), pp. 1-39. https://doi.org/10.3390/en10111760.

[7] A. Shahmohammadi, R. Sioshansi, A.J. Conejo, S. Afsharnia, The role of energy storage in mitigating ramping inefficiencies caused by variable renewable generation, Energy Conversion and Management, vol. 162, (2018), pp. 307-320. https://doi.org/10.1016/j.enconman.2017.12.054.

[8] A.J. Lamadrid, Optimal use of energy storage systems with renewable energy sources, International Journal of Electrical Power \& Energy Systems, vol. 71, (2015), pp. 101-111. https://doi.org/10.1016/j.ijepes.2015.01.025.

[9] Y. Yang, S. Bremner, C. Menictas, M. Kay, Battery energy storage system size determination in renewable energy systems: A review, Renewable and Sustainable Energy Reviews, vol. 91, (2018), pp. 109-125. https://doi.org/10.1016/i.rser.2018.03.047.

[10] H. Branco, R. Castro, A.S. Lopes, Battery energy storage systems as a way to integrate renewable energy in small isolated power systems, Energy for Sustainable Development, vol. 43, (2018), pp. 90 99. https://doi.org/10.1016/j.esd.2018.01.003.

[11] A.K. Rohit, K.P. Devi, S. Rangnekar, An overview of energy storage and its importance in Indian renewable energy sector: Part I Technologies and Comparison, Journal of Energy Storage, vol. 13, (2017), pp. 10-23. https://doi.org/10.1016/j.est.2017.06.005.

[12] S.O. Amrouche, D. Rekioua, T. Rekioua, S.Bacha, Overview of energy storage in renewable energy systems, International Journal of Hydrogen Energy, vol. 41, no. 45, (2016), pp. 20914-20927. https://doi.org/10.1016/j.ijhydene.2016.06.243.

[13] Y. Zheng, B.M. Jenkins, K. Kornbluth, C. Træholt, Optimization under uncertainty of a biomass-integrated renewable energy microgrid with energy storage, Renewable Energy, vol. 123, (2018), pp. 204-217. https://doi.org/10.1016/j.renene.2018.01.120.

[14] T. Bocklisch, Hybrid energy storage approach for renewable energy applications, Journal of Energy Storage, vol. 8, (2016), pp. 311-319. https://doi.org/10.1016/j.est.2016.01.004.

[15] M. Winfield, S. Shokrzadeh, A. Jones, Energy policy regime change and advanced energy storage: A comparative analysis, En- 
ergy Policy, vol. 115, (2018), pp. 572-583. https://doi.org/10.1016/j.enpol.2018.01.029.

[16] A.A. Solomon, M. Child, U. Caldera, C. Breyer, How much energy storage is needed to incorporate very large intermittent renewables?, Energy Procedia, vol. 135, (2017), pp. 283-293. https://doi.org/10.1016/j.egypro.2017.09.520.

[17] M. Assembayeva, N. Zhakiyev, Y. Akhmetbekov, Impact of storage technologies on renewable energy integration in Kazakhstan, Materialstoday: Proceedings, vol. 4, no. 3, Part A, (2017), pp. 45124523. https://doi.org/10.1016/j.matpr.2017.04.024.

[18] T. Trainer, Some problems in storing renewable energy, Energy Policy, vol. 110, (2017), pp. 386-393. https://doi.org/10.1016/j.enpol.2017.07.061.

[19] J.I. San Martín, I. Zamora, J.J. San Martín, V. Aperribay, P. Eguía Energy Storage Technologies for Electric Applications. Available [Online]: $\quad$ http://www.sc.ehu.es/sbweb/energiasrenovables/temas/almacenamiento/almacenamiento.html

[20] Integrating Renewable Electricity on the Grid, A Report by the APS Panel on Public Affairs, Technical Report. Available. [online]: https://www.aps.org/policy/reports/popareports/upload/integratingelec.pdf

[21] A.K. Rohit, S. Rangnekar, An overview of energy storage and its importance in Indian renewable energy sector: Part II - energy storage applications, benefits and market potential, Journal of Energy Storage, vol. 13, (2017), pp. 447-456 https://doi.org/10.1016/j.est.2017.07.012.

[22] A.G. Olabi, Renewable energy and energy storage systems, Energy, vol. 136, (2017), pp. https://doi.org/10.1016/j.energy.2017.07.054.

[23] E.A. Pina, M.A. Lozano, L.M. Serra, Allocation of economic costs in trigeneration systems at variable load conditions including renewable energy sources and thermal energy storage, Energy, vol. 151, (2018), pp. 633-646. https://doi.org/10.1016/j.energy.2018.03.083.

[24] M.D. Leonard, E.E. Michaelides, D.N. Michaelides, Substitution of coal power plants with renewable energy sources - Shift of the power demand and energy storage, Energy Conversion and Management, vol. 164, (2018), pp. 27-35. https://doi.org/10.1016/j.enconman.2018.02.083.

[25] S.O. Amrouche, D. Rekioua, T. Rekioua, Overview of energy storage in renewable energy systems, 3rd International Renewable and Sustainable Energy Conference, Marrakech, (2015), pp. 1-6. https://doi.org/10.1109/IRSEC.2015.7454988.

[26] E.O. Ogunniyi, H. Pienaar, Overview of battery energy storage system advancement for renewable (photovoltaic) energy applications, International Conference on the Domestic Use of Energy, Cape Town, (2017), $233-239$. https://doi.org/10.23919/DUE.2017.7931849.

[27] S. Surender Reddy, V. Sandeep, Chan-Mook Jung, Review of Stochastic Optimization Methods for Smart Grid, Frontiers in Energy, vol. 11, no. 2, (2017), pp. 197-209. https://doi.org/10.1007/s11708017-0457-7.

[28] James A. Momoh, S. Surender Reddy, Review of Optimization Techniques for Renewable Energy Resources, IEEE Symposium on Power Electronics \& Machines for Wind and Water Application (PEMWA), Milwaukee, WI, July 2014, pp. 1-8 https://doi.org/10.1109/PEMWA.2014.6912225.

[29] A. Alhamali, M.E. Farrag, G. Bevan, D.M. Hepburn, Review of Energy Storage Systems in electric grid and their potential in distribution networks, Eighteenth International Middle East Power Systems Conference, Cairo, (2016), pp. 546-551. https://doi.org/10.1109/MEPCON.2016.7836945.

[30] A.A. Jamali, N.M. Nor, T. Ibrahim, Energy storage systems and their sizing techniques in power system: A review, IEEE Conference on Energy Conversion, Johor Bahru, (2015), pp. 215-220. https://doi.org/10.1109/CENCON.2015.7409542.

[31] B.J. Donnellan, D.J. Vowles, W.L. Soong, A review of energy storage and its application in power systems, Australasian Universities Power Engineering Conference, Wollongong, NSW, (2015), pp. 1-6. https://doi.org/10.1109/AUPEC.2015.7324839.

[32] J.C. Beardsall, C.A. Gould, M. Al-Tai, Energy storage systems: A review of the technology and its application in power systems, 50th International Universities Power Engineering Conference, Stoke on Trent, (2015), pp. 1-6. https://doi.org/10.1109/UPEC.2015.7339794

[33] K.J. Seog, S.S. Reddy, C.M. Jung, Solving Non-convex Economic Dispatch with Prohibited Zones using Artificial Fish Swarm Optimization, International Journal of Engineering \& Technology, vol. 7, no. 2.18, (2018), pp. https://doi.org/10.14419/ijet.v7i2.18.11200.
[34] S.S. Reddy, C.M. Jung, Overview of Energy Storage Technologies: A Techno-Economic Comparison, International Journal of Applied Engineering Research, vol. 12, no. 22, (2017), pp. 12872-12879.

[35] Y. Ma, P. Yang, X. Zhou, Z. Gao, Research review on energy storage technology, IEEE International Conference on Mechatronics and Automation, Harbin, (2016), pp. 159-164 https://doi.org/10.1109/ICMA.2016.7558553.

[36] A. Lachuriya, R.D. Kulkarni, Stationary electrical energy storage technology for global energy sustainability: A review, International Conference on Nascent Technologies in Engineering, Navi Mumbai, (2017), pp. 1-6. https://doi.org/10.1109/ICNTE.2017.7947936.

[37] S.S. Reddy, Optimal scheduling of wind-thermal power system using clustered adaptive teaching learning based optimization, Electrical Engineering, vol. 99, no. 2, (2017), pp. 535-550. https://doi.org/10.1007/s00202-016-0382-5.

[38] S.S. Reddy, Optimal Power Flow with Renewable Energy Resources including Storage, Electrical Engineering, vol. 99, no. 2, (2017), pp. 685-695. https://doi.org/10.1007/s00202-016-0402-5.

[39] S.S. Reddy, Optimizing Energy and Demand Response Programs using Multi-Objective Optimization, Electrical Engineering, vol. 99, no. 1, (2017), pp. 397-406. https://doi.org/10.1109/ISGTAsia.2015.7387040.

[40] X. Zhou, Z. Fan, Y. Ma, Z. Gao, Research review on electrical energy storage technology, 36th Chinese Control Conference, Dalian, (2017), pp.

10674-10678. https://doi.org/10.23919/ChiCC.2017.8029057.

[41] N. Kawakami, Y. Iijima, Overview of battery energy storage systems for stabilization of renewable energy in Japan, International Conference on Renewable Energy Research and Applications, Nagasaki, (2012), pp. https://doi.org/10.1109/ICRERA.2012.6477391.

[42] A. Fraleoni-Morgera, V. Lughi, Overview of Small Scale Electric Energy Storage Systems suitable for dedicated coupling with Renewable Micro Sources, International Conference on Renewable Energy Research and Applications, Palermo, (2015), pp. 1481-1485. https://doi.org/10.1109/ICRERA.2015.7418653. 